\title{
POPULARITY IN SOCIAL MEDIA AND COMPANY GROWTH: EVIDENCE FOR LOCAL BANKS
}

\author{
Łukasz KOZŁOWSKI $\underline{-1}^{1 *}$, Iwa KUCHCIAK (D) ${ }^{2}$ \\ ${ }^{I}$ Department of Banking, Insurance and Risk, Kozminski University, Jagiellońska 57/59, 03-301, Warsaw, Poland \\ ${ }^{2}$ Institute of Finance, Faculty of Economics and Sociology, University of Lodz, POW nr 3/5, 90-255, Lodz, Poland \\ "E-mail: lkozlowski@kozminski.edu.pl
}

\begin{abstract}
Purpose - we investigate models of social media activity of small local banks (SLBs) in Poland and the consequences of their adoption for SLBs' growth.

Research methodology - with the use of k-medoid clustering, we differentiate between types of SLBs' social media activity. Then, after controlling for bank specificity and local environment, we employ these activity types in regression models explaining a bank's popularity in social media and bank growth.
\end{abstract}

Findings - although SLBs draw attention if they concentrate their social media activity on local affairs, conversion of such popularity into a bank growth is difficult to achieve.

Research limitations - a relatively limited number of SLBs (111 entities) adopted an active social media policy. As a result, we have to look for social media activity models instead of describing the activity directly with numerous variables employed simultaneously in regressions.

Practical implications - in order to reach the highest recognition in social media, a small bank should widely discuss local affairs. Nevertheless, SLBs' managers should carefully enter the social media world as even suitably selected social media strategy does not automatically lead to economic outcomes.

Originality/Value - first, we extend the scarce evidence on social media adoption by financial companies. Second, we clearly define different types of social media activity of local firms. Third, we differentiate between the attention drawn through social media activity and its economic repercussions.

Keywords: local banks, cooperative banks, social media, Facebook, consumer attention, bank growth.

JEL Classification: M310, G21.

Conference topic: Contemporary Financial Management.

\section{Introduction}

Within distribution and communication channels of a modern company, social media become a natural companion and sometimes a successor of a company's general Internet activity. Social media give new possibilities of strengthening a company's relationship with its clients through spreading positive word-of-mouth, addressing individual customer expectations, improving day-to-day communication or allowing for direct or indirect presentation of a company's offer. Taking additionally into account that the number of social media users is consistently growing and is expected to exceed 3 billion users by 2021 (eMarketer, 2017), it is not surprising that social media shift to the center of interests of not only entrepreneurs but also researchers. Current empirical evidence related to the impact of social media on economic life concerns mostly: (a) the strengthening of a customer-company relationship and engagement (Mangold \& Faulds, 2009; Kaplan \& Haenlein, 2010; Bolton, 2011; Tsimonis \& Dimitriadis, 2014; Laroche, Habibi, Richard, \& Sankaranarayanan, 2012; Lipsman, Mudd, Rich, \& Bruich, 2012; Durkin, McGowan, \& Murray, 2014), (b) improved efficiency of marketing (Edelman, 2010; Gallaugher \& Ransbotham, 2010; Pozza, 2014; Cawsey \& Rowley, 2016), or (c) stimulation of brand awareness and loyalty (Silver \& Vegholm, 2009; Farshid, Plangger, \& Nel, 2011; Laroche, Habibi, \& Richard, 2013; Larsson \& Vitaoja, 2017). Contributions related to financial aspects of social media adoption are relatively scarce, and concern mostly non-financial companies and links between social media investment and firm value or performance (Plangger, 2012; Paniagua \& Sapena, 2014; Kim, Koh, Cha, \& Lee 2015a; Kim, Lim, \& Brymer, 2015b; Hsu \& Lawrance, 2016). Within that context, the literature strand related to social media impact on financial

(C) 2019 Author. Published by VGTU Press. This is an open-access article distributed under the terms of the Creative Commons Attribution (http://creativecommons.org/licenses/by/4.0/) License, which permits unrestricted use, distribution, and reproduction in any medium, provi-ded the original author and source are credited. 
companies seems especially underdeveloped (Filip, Jackowicz, \& Kozłowski, 2017; Tang, Mehl, Eastlick, \& Card, 2016).

Our research project investigates models of social media activity of small local banks (SLBs) in Poland and the consequences of their adoption for SLBs' growth. The study has two goals. On the one hand, we investigate which thematic content of social media activity contributes to increased popularity among social media users. On the other hand, we check whether the attention in social media finally stimulates bank growth. To achieve our goals we employ three data sources, that is, a hand-collected dataset describing the specificity of Facebook activity of small local banks (SLBs) in Poland, financial statements of those banks, as well as information about local economic environment for the areas in which the banks operate. After combining the data, we implement a stepwise research strategy. First, taking into account the previous empirical findings, the local character of analyzed banks, and their organizational form (cooperatives), we distinguish different Facebook activity models and check what kind of social media activity ensures popularity among Facebook users. Then, in the second step of our study, we relate the recognized Facebook activity models to a bank growth in order to verify whether the initial attention gains resulting from employed Facebook activities have economic repercussions for SLBs' growth. The collected evidence allows us to conclude that SLBs, as expected, are able to draw attention if they concentrate their social media activity on local affairs, but the conversion of this attention into a bank growth is difficult to achieve.

Our study contributes to financial literature in three ways. First, we extend the scarce evidence on social media adoption by financial companies, including banks, and its economic consequences ${ }^{1}$. In contrast, the existing studies concentrate mostly on non-financial firms or marketing aspects of social media adoption. Second, we clearly define different types of social media activity of local firms, and their consequences for the popularity among social media users, that is, we analyze not only the extent of social media activity but also its content in the context of identified thematic Facebook activity models. Third, we strictly differentiate between the initial attention gains resulting from Facebook activity and their final economic repercussions.

The remainder of this paper is structured in five parts. First, we provide an institutional background. Second, we discuss the literature and existing empirical evidence. Third, we outline the data and methodology. The fourth section discusses the results, while the fifth section concludes.

\section{Institutional background}

The Polish banking sector is constituted by mostly large supra-local commercial banks and SLBs. The former group is composed of 62 entities ${ }^{2}$, while 554 cooperative banks make up the latter category. ${ }^{3}$ Although cooperative banks hold $9.4 \%$ of the banking sector's assets and $9.9 \%$ of deposits from non-financial entities, they provide payments to almost $20 \%$ of people employed in the sector (Polish Financial Supervision Authority, 2017). This is a result of a widespread network of numerous branches, mostly located in less urbanized areas. Although cooperatives in the banking sector serve clients from the whole country, individual banks are strictly local entities. An average cooperative bank operates through 8 branches, located in less than 1\% of counties, with the median distance between a bank's head office and its branch not exceeding $12 \mathrm{~km}$ for half of the banks. In comparison, for commercial banks, the same measure equals $252 \mathrm{~km}$. Generally, cooperative banks follow unique business strategies, as they combine strictly commercial functions (offering of banking products) with the support to their local communities in different cultural or social projects. Nevertheless, the cooperative sector has been consistently undergoing commercialization, and banks are becoming increasingly similar to their purely commercial counterparts.

Strong competition in the Polish banking sector forces cooperative banks to reach customers through new communication channels, including social media. The first cooperative bank adopted Facebook as its communication channel in 2010, and the number of Facebook-active cooperative banks consistently grew to $112^{4}$ entities in 2016 (around one-fifth of the banks in the cooperative sector). Nevertheless, the remaining social media channels are much less used. At the end of 2016, a group of 82 cooperative banks had published films on YouTube, and only 15 entities were active on GoldenLine (a Polish equivalent to LinkedIn), 4 on Instagram, 3 on LinkedIn, and just 1 on Twitter.

\section{Literature review}

Within the contributions on social media adoption by financial and non-financial companies, two strands of literature can be distinguished. The first one concerns the thematic content of a company's social media presence and its impact on customer attention, while the second one focuses on the impact of social media presence on firm performance.

\footnotetext{
${ }^{1}$ In a more general sense, the study also contributes to the literature on the consequences of the adoption of electronic distribution channels (e.g., Hitt \& Frei, 2002; Hernando \& Nieto, 2007; Delgado, Hernando, \& Nieto, 2007; DeYoung, Lang, \& Nolle, 2007; Ciciretti, Hasan, \& Zazzara, 2009; Onay \& Ozsoz, 2013).

2 The group includes 35 banks domiciled in Poland and 27 branches of foreign financial institutions.

${ }^{3}$ As per end of July 2017.

${ }^{4}$ In our study we exclude one Facebook-active SLB from the total sample due to unavailability of its financial data.
} 
Within the first abovementioned literature strand, the authors prove that social media strengthen long-term relationships with clients (Mangold \& Faulds, 2009; Kaplan \& Haenlein, 2010; Laroche et al., 2012; Lipsman et al., 2012; Durkin et al., 2014), improve efficiency of marketing efforts (Edelman, 2010; Gallaugher \& Ransbotham, 2010; Pozza, 2014; Cawsey \& Rowley, 2016), generally increase consumer engagement (Bolton, 2011; Tsimonis \& Dimitriadis, 2014), and stimulate brand awareness, loyalty, and trust (Silver \& Vegholm, 2009; Farshid et al., 2011; Laroche et al., 2013; Larsson \& Vitaoja, 2017). As far as the content type of social media activity is concerned, it is shown that the characteristics of Facebook posts such as post type, category, and posting day influence users' interaction in terms of the number of comments and likes, as well as its duration (Cvijikj \& Michahelles, 2011). In a similar manner, Swani and Milne (2017) demonstrate that Facebook service messages generate more attention (measured by the number of comments) than goods messages, while Swani, Milne, and Brown (2013) suggest that the popularity of social media content is driven by the level of its functional and emotional appeals. In this respect, Ozdora-Aksaka and AtakanDuman (2015) point out that Turkish banks construct their identity by emphasizing their softer side (especially the socially responsible one) on social media accounts (Facebook and Twitter). Thus, companies recognize the power of meaningful posts without unsolicited sales messages (Hansson, Wrangmo, \& Søilen, 2013) and seem to know that social responsibility is rewarded with more positive customer attitudes and higher levels of customer retention (van Doorn, Onrust, Verhoef, \& Bügel, 2017). As a result, companies adjust the thematic specificity of their social media activity. Taking into account the existing empirical evidence from the first literature strand, the local character of banks from our sample, and their organizational form (cooperatives), we pose the first research hypothesis:

\section{H1: SLBs are the most popular in social media when their social media activity concentrates on local matters.}

Authors from the second literature strand point out the financial effects of a company's social media activity. Plangger (2012) and Hsu and Lawrance (2016) provide evidence on a positive relationship between social media investment and electronic word-of-mouth, on the one hand, and firm value, on the other hand. In a similar manner, Kim et al. (2015b) prove that overall rating in social media is the most salient predictor of hotel performance. Nevertheless, Paniagua and Sapena (2014) indicate that the positive effect of social media on firm value is exerted only if a critical mass of social media followers is attained. In the context of the banking industry, Tang et al. (2016) analyze the relationship between electronic word-of-mouth and firm profitability for a sample of 68 US banks and find that both star ratings and verbalized emotions (especially negative ones) are good predictors of bank performance. In the context of SLBs, Filip et al. (2017) show less encouraging aspects of social media activity. While they admit that social media presence can be a bank's valuable asset, they also highlight that SLBs have to forego some of their market power to open the possibility of reaching customers through new communication tools, especially when such tools are adopted relatively late and there is strong competition with other banks that are more advanced in social media or the Internet. As the existing empirical evidence indicates that the relationship between social media activity and firm performance could be conditional (critical mass of social media followers or sacrifice of market power may be required) or could be generally less achievable for late social media adopters and smaller companies, we formulate the second hypothesis in the following manner:

H2: SLB's high recognition in social media does not automatically lead to SLB's growth.

\section{Data description and methodology}

In our study, we employ three data sources. First, we utilize a unique, hand-collected dataset describing the Facebook activity of 111 SLBs in Poland. The dataset covers the period from 2010 to 2016, during which the banks published 19,024 posts. The median value of posts per bank is 111; a quarter of banks published less than 27 posts, while another quarter generated more than 241 posts. We classify posts into 8 categories, depending on the type of information they convey. The categories are: (a) advertisements, (b) educational materials, (c) posts expressing thanks, wishes, or congratulations to local community members, (d) posts about local issues, (e) information on local charitable activities, (f) curiosities and news, (g) notifications about branch unavailability, and (h) posts which cannot be assigned to the other categories. We calculate the share of posts published each year within these categories in order to get 8 variables that define a bank's informational profile on Facebook: ADS, EDU, THANKS, LOCAL, CHARITY, CURIOS, UNA$V A I L$, and $O T H E R$, respectively. Apart from that, we describe Facebook users' response to the banks' activity by calculating the number of (a) likes, (b) shares (share button clicks), and (c) total comments for each post published between 2010 and 2016. Consequently, we obtain the following variables: LIKES, SHARES, and COMM, which we collectively call response variables. Panels A and B of Table 1 present detailed definitions of the variables related to SLBs' Facebook activity and users' response.

Facebook users' response to a bank's social media activity can be driven by different factors, some of them unrelated to a bank's Facebook activity profile. Thus, in order to adequately measure the impact of a bank's informational profile on Facebook users' responses, we enrich our dataset with information from two additional sources. First, we utilize SLBs' financial statements for the analyzed time period. Second, from the Polish Central Statistical Office, we gather information on the local economic environment, i.e., on counties in which SLBs operate. Those additional datasets allow us to construct two sets of variables, which are then employed as regressors (in our models explaining 
Facebook users' response to SLBs' social media activity) or as dependent variables (in models explaining SLBs' growth). First, we describe each bank's financial characteristic in the analyzed period ${ }^{5}$ by measuring a bank's size $(L N . A)$, profitability $(R O A)$, interest margin (NIM), solvency (EQUITY), asset structure (LOANS), deposit growth rate $(D E P O \Delta)$, loan growth rate $(L O A N \Delta)$ and asset growth rate $(A S S E T \Delta)$. Second, we describe a bank's local environment with the population density $(P O P U L)$, unemployment rate $(U N E M P L)$ and the urbanization level (URBANIZ). Panels $\mathrm{C}$ and $\mathrm{D}$ of Table 1 provide detailed definitions of the control variables, while Table 2 presents the relevant descriptive statistics of all variables in our study.

Table 1. Variable definitions

\begin{tabular}{|c|c|}
\hline \multicolumn{2}{|c|}{ Panel A. Bank's informational profile on Facebook between 2010 and 2016} \\
\hline$A D S$ & The share of advertising posts in all posts published by a bank \\
\hline$E D U$ & $\begin{array}{l}\text { The share of educational posts (including information about the specificity of banking products) in all posts } \\
\text { published by a bank }\end{array}$ \\
\hline THANKS & $\begin{array}{l}\text { The share of posts expressing thanks, wishes, or congratulations addressed to local community members in all } \\
\text { posts published by a bank }\end{array}$ \\
\hline LOCAL & The share of posts about local issues in all posts published by a bank \\
\hline CHARITY & The share of posts related to local charitable activities in all posts published by a bank \\
\hline CURIOS & The share of posts about curiosities and news in all posts published by a bank \\
\hline UNAVAIL & The share of posts about branch unavailability in all posts published by a bank \\
\hline OTHER & The share of all other posts (not included in the above categories) in all posts published by a bank \\
\hline \multicolumn{2}{|c|}{ Panel B. Facebook users' response between 2010 and 2016} \\
\hline LIKES & The ratio of the number of likes by Facebook users to the number of a bank's posts \\
\hline SHARES & The ratio of the number of shares by Facebook users to the number of a bank's posts \\
\hline COMM & The ratio of the number of comments by Facebook users to the number of a bank's posts \\
\hline \multicolumn{2}{|c|}{ Panel C. Banks' financial characteristics (average values over the period 2009-2015) } \\
\hline$L N . A$ & Natural logarithm of total assets in constant prices \\
\hline EQUITY & The ratio of equity to total assets \\
\hline$R O A$ & Operating return on average assets \\
\hline NIM & The ratio of net interest income to average assets \\
\hline LOANS & The ratio of loans to total assets \\
\hline DEPOA & The yearly growth rate of deposits in constant prices \\
\hline$L O A N \Delta$ & The yearly growth rate of loans in constant prices \\
\hline ASSETA & The yearly growth rate of assets in constant prices \\
\hline \multicolumn{2}{|c|}{ Panel D. Local environment (average values over the period 2009-2015)* } \\
\hline UNEMPL & The unemployment rate in counties in which a bank operates \\
\hline POPUL & Population density in thousands of inhabitants $/ \mathrm{km}^{2}$ \\
\hline URBANIZ & Percentage of urban population in counties in which a bank operates \\
\hline
\end{tabular}

*Values were averaged over counties in which a bank operated with a number of a bank's branches in individual counties used as weights.

\footnotetext{
${ }^{5}$ We take into account the period of 2010-2015 and average yearly observations for each bank.
} 
Table 2. Descriptive statistics

\begin{tabular}{|c|c|c|c|c|c|c|c|c|}
\hline Variable & Banks & Mean & Std. Dev. & Min & $1^{\text {st }}$ Quartile & $2^{\text {nd }}$ Quartile & $3^{\text {rd }}$ Quartile & Max \\
\hline$A D S$ & 111 & 0.300 & 0.179 & 0.000 & 0.202 & 0.264 & 0.364 & 1.000 \\
\hline$E D U$ & 111 & 0.158 & 0.157 & 0.000 & 0.049 & 0.108 & 0.215 & 1.000 \\
\hline THANKS & 111 & 0.182 & 0.145 & 0.000 & 0.073 & 0.155 & 0.274 & 1.000 \\
\hline LOCAL & 111 & 0.082 & 0.101 & 0.000 & 0.000 & 0.057 & 0.121 & 0.636 \\
\hline CHARITY & 111 & 0.046 & 0.062 & 0.000 & 0.000 & 0.021 & 0.070 & 0.265 \\
\hline CURIOS & 111 & 0.068 & 0.102 & 0.000 & 0.000 & 0.035 & 0.100 & 0.696 \\
\hline UNAVAIL & 111 & 0.011 & 0.027 & 0.000 & 0.000 & 0.000 & 0.015 & 0.221 \\
\hline OTHER & 111 & 0.152 & 0.159 & 0.000 & 0.058 & 0.123 & 0.199 & 1.000 \\
\hline LIKES & 111 & 4.725 & 4.810 & 0.000 & 2.101 & 3.459 & 5.600 & 33.788 \\
\hline SHARES & 111 & 0.688 & 1.066 & 0.000 & 0.073 & 0.253 & 0.788 & 5.228 \\
\hline COMM & 111 & 0.303 & 1.004 & 0.000 & 0.020 & 0.103 & 0.258 & 10.160 \\
\hline$L N . A$ & 111 & 18.689 & 0.829 & 17.015 & 18.004 & 18.684 & 19.232 & 21.345 \\
\hline EQUITY & 111 & 0.106 & 0.029 & 0.051 & 0.086 & 0.101 & 0.121 & 0.191 \\
\hline NIM & 111 & 0.036 & 0.007 & 0.018 & 0.031 & 0.035 & 0.039 & 0.061 \\
\hline$R O A$ & 111 & 0.010 & 0.004 & -0.001 & 0.007 & 0.010 & 0.013 & 0.020 \\
\hline LOANS & 111 & 0.785 & 0.132 & 0.355 & 0.707 & 0.831 & 0.878 & 0.971 \\
\hline 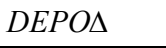 & 111 & 0.117 & 0.076 & -0.050 & 0.069 & 0.103 & 0.160 & 0.455 \\
\hline$L O A N \Delta$ & 111 & 0.099 & 0.090 & -0.256 & 0.037 & 0.092 & 0.156 & 0.386 \\
\hline ASSETA & 111 & 0.109 & 0.068 & -0.034 & 0.064 & 0.096 & 0.145 & 0.414 \\
\hline$U N E M P L$ & 111 & 0.129 & 0.048 & 0.037 & 0.090 & 0.125 & 0.166 & 0.284 \\
\hline POPUL & 111 & 0.259 & 0.265 & 0.038 & 0.078 & 0.135 & 0.361 & 1.599 \\
\hline URBANIZ & 111 & 0.467 & 0.161 & 0.037 & 0.357 & 0.444 & 0.583 & 0.862 \\
\hline
\end{tabular}

In order to verify our hypotheses, we apply a stepwise procedure. First, with the use of k-medoid clustering, we assign each bank to a Facebook activity model, depending on the information structure conveyed in its posts. The objective of this approach is to group banks with similar informational profiles into the same cluster (Kaufman \& Rousseeuw, 1990). The k-medoid algorithm uses the Euclidean distance to identify clusters by minimizing the differences between variables reflecting the informational profiles of different banks ( $A D S, E D U, T H A N K S, L O C A L, C H A R-$ ITY, CURIOS, UNAVAIL, and OTHER). The method allows us not only to identify business models but also - as a result - to reduce the number of variables needed to describe a bank's informational profile. This is a desirable advantage in the remaining steps of our analysis, wherein we relate Facebook users' response or SLBs' growth to different activity profiles of SLBs. In the second step, we follow a univariate approach and test for differences in means of the response variables (LIKES, SHARES, and COMM) for each pair of Facebook activity models. Apart from the parametric t-test, we also apply a non-parametric Mann-Whitney U test to determine whether responses to two different Facebook activity models originate from the same or different distributions. In the third step, we estimate regression models through the OLS estimator with robust standard errors. These models explain Facebook users' responses to a bank's posts with a set of control variables, including a bank's financial characteristics and the specificity of its local environment, as well as a set of dummies identifying a bank's Facebook activity model. The general construction of our models is illustrated by Eq. (1).

$$
D E P_{\mathrm{it}}=\mathrm{f}\left(F I N_{\mathrm{i}} ; E N V_{\mathrm{i}} ; F A M_{\mathrm{i}}\right),
$$

where $D E P_{\mathrm{i}}$ is a dependent variable representing Facebook users' responses to the i-th bank's Facebook activity model (LIKES, SHARES, and COMM). The set of independent variables includes a bank's financial characteristics (denoted collectively as $F I N)$, its local environment $(E N V)$, and a set of binary variables $(F A M)$ coding the Facebook activity models (previously identified through the k-medoid clustering).

From the perspective of an SLB, a suitable model of Facebook activity may stimulate the attention of Facebook users (hypothesis H1). Nevertheless, it does not have to automatically lead to the acquisition of customers and to bank growth. Therefore, within the fourth step of our study, we finally verify hypothesis $\mathrm{H} 2$. Thus, we substitute indicators of SLBs' growth (DEPO $\Delta, \mathrm{LOAN} \Delta, \mathrm{ASSET} \Delta$ ) for the original dependent variables in Eq. (1), and regress them against the set of controls from three different groups, that is FIN, ENV and FAM. 


\section{Results}

\subsection{Facebook activity models}

We begin our analysis with a k-medoid clustering, which allows us to identify 3 unique Facebook activity models of SLBs. The results of the clustering are presented in Table 3. The banks in our study are almost uniformly scattered between clusters, as none of the groups comprises more than $36 \%$ of the total population. The first cluster includes 39 banks that devoted their Facebook activity mainly to product advertising: the medoid, that is, a group representative, conveys advertisements in the $41.0 \%$ of its posts, while $24.1 \%$ of posts reflect educational materials that also include information about the specificity of the products offered. Additionally, banks within this cluster do not inform their Facebook followers about local issues nor local charitable events. Taking all these specificities into account, we call this model the Advertiser. The second cluster is constituted by 35 SLBs. The medoid of this group (i.e., a typical bank from this group) conveys information about local issues, local charitable activities, as well as thanks, wishes, and congratulations addressed to members of the local community in the $54.7 \%$ of its posts. The dominance of local issues in the posts of SLBs from the second group prompts us to call this model the Local Informant. Finally, the third cluster includes 37 banks. The prevalence of other issues (OTHER) without any dominant character in the posts, as well as a

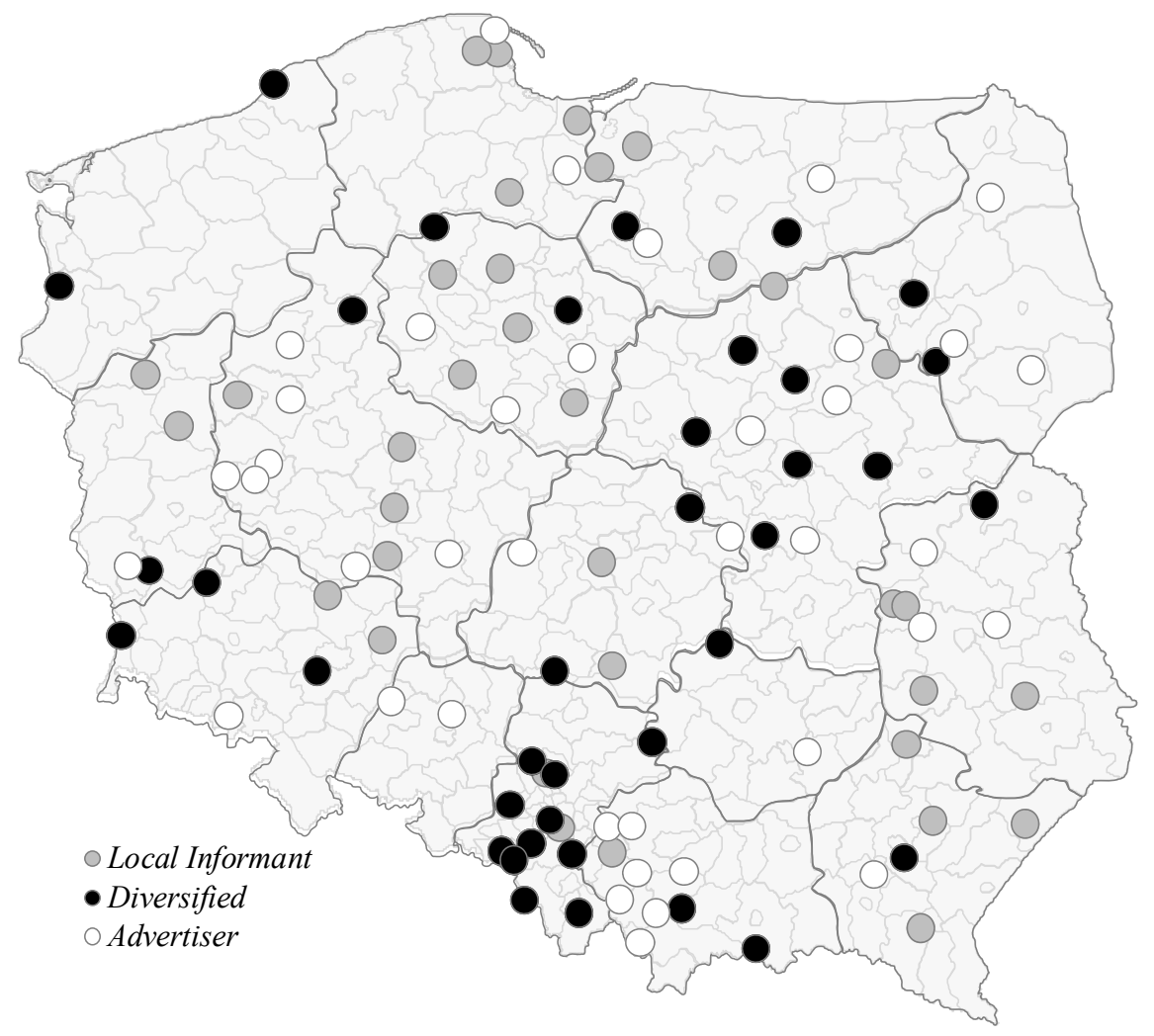

Figure 1. Geographical distribution of head offices of SLBs with different Facebook activity models (source: author's own presentation)

Table 3. SLBs' Facebook activity models (k-medoid clustering)

\begin{tabular}{|c|c|c|c|c|}
\hline \multirow{5}{*}{ Medoids } & Clustering variable & $\begin{array}{c}\text { Cluster 1 } \\
\text { (Advertiser) }\end{array}$ & $\begin{array}{c}\text { Cluster 2 } \\
\text { (Local Informant) }\end{array}$ & $\begin{array}{c}\text { Cluster 3 } \\
\text { (Diversified) }\end{array}$ \\
\hline \multirow{5}{*}{} & ADS & $41.0 \%$ & $23.1 \%$ & $22.6 \%$ \\
\cline { 2 - 5 } & EDU & $24.1 \%$ & $10.8 \%$ & $9.6 \%$ \\
\cline { 2 - 5 } & THANKS & $25.3 \%$ & $27.8 \%$ & $14.1 \%$ \\
\cline { 2 - 5 } & LOCAL & $0.0 \%$ & $15.6 \%$ & $7.2 \%$ \\
\cline { 2 - 5 } & CHARITY & $1.2 \%$ & $11.3 \%$ & $3.7 \%$ \\
\cline { 2 - 5 } & CURIOS & $1.2 \%$ & $2.8 \%$ & $13.6 \%$ \\
\cline { 2 - 5 } & UNAVAIL & $2.4 \%$ & $0.0 \%$ & $0.5 \%$ \\
\hline & OTHER & $4.8 \%$ & $8.5 \%$ & $28.7 \%$ \\
\hline Number of banks in the cluster & & 39 & 35 & 37 \\
\hline
\end{tabular}


relatively uniform share of advertisements and posts commenting local issues (THANKS, LOCAL, and CHARITY), suggest treating this model as the Diversified one. Figure 1 shows the geographical distribution of SLBs following different Facebook activity models. The banks are spread all over the country, and there is no evident regularity in the location of banks from the same cluster, apart from two groups following the Advertiser and the Diversified models in the South of the country. Thus, we reckon that regional factors do not impact significantly the SLBs' choice of their Facebook activity models.

\section{Response to the Facebook activity models}

Table 4 presents the means and medians of the response variables (LIKES, SHARES, and COMM) in each cluster. For each response variable and each pair of clusters, we additionally perform a test for differences in means and the nonparametric Mann-Whitney U test. It should be noted that SLBs classified as Local Informants (on the basis of their informational activity on Facebook) present the highest average number of likes, shares, and comments per post: 7.2, 1.2, and 0.7, respectively. The respective differences in means (in relation to the Advertiser and the Diversified models) are statistically significant: in 2 cases at levels below $1 \%$, in 3 cases at levels between $1 \%$ and $5 \%$, and in one case at levels between $5 \%$ and $10 \%$. As for the Mann-Whitney U test, the differences between the distributions in samples are even more evident, as in 5 out of 6 cases the Local Informant model proves to be the most attractive to Facebook users at levels below $1 \%$, and in 1 case at levels between $1 \%$ and $5 \%$. Indeed, the median of likes per post in the Local Informant model exceeds the corresponding values in both remaining models by almost twice. In the case of shares per post and comments per post, the Local Informant records medians of 0.5 and 0.3 , while both remaining models do not reach even half of these values. In contrast, it is worth emphasizing that there are no statistically significant differences in Facebook users' responses between the Advertiser and the Diversified models. Such differences in means or medians are even irregular; specifically, in terms of average shares and comments per post, the Diversified model outperforms the Advertiser one, while the opposite occurs for median likes and comments per post.

Table 4. Univariate analysis. Response to SLBs' Facebook activity models (source: author's own calculations)

\begin{tabular}{|c|c|c|c|c|c|c|c|c|}
\hline \multirow{3}{*}{$\begin{array}{l}\text { Response } \\
\text { variable }\end{array}$} & \multirow{2}{*}{\multicolumn{2}{|c|}{ Cluster names }} & \multicolumn{3}{|c|}{$\begin{array}{c}\text { Parametric } \\
\text { test for differences in means }\end{array}$} & \multicolumn{3}{|c|}{$\begin{array}{c}\text { Non-parametric } \\
\text { Mann-Whitney U test }\end{array}$} \\
\hline & & & \multicolumn{2}{|c|}{ Means } & \multirow[t]{2}{*}{ t statistic } & \multicolumn{2}{|c|}{ Medians } & \multirow[t]{2}{*}{ Z statistic } \\
\hline & Cluster A & Cluster B & Cluster A & Cluster B & & Cluster A & Cluster B & \\
\hline LIKES & Advertiser & Diversified & 3.131 & 4.036 & -0.938 & 3.000 & 2.761 & -0.270 \\
\hline LIKES & Advertiser & Local Inf. & 3.131 & 7.229 & $-4.528 * * *$ & 3.000 & 5.250 & $-3.789 * * *$ \\
\hline LIKES & Diversified & Local Inf. & 4.036 & 7.229 & $-2.520 * *$ & 2.761 & 5.250 & $-3.448 * * *$ \\
\hline SHARES & Advertiser & Diversified & 0.519 & 0.382 & 0.867 & 0.184 & 0.159 & 0.344 \\
\hline SHARES & Advertiser & Local Inf. & 0.519 & 1.200 & $-2.488^{* *}$ & 0.184 & 0.504 & $-2.312^{* *}$ \\
\hline SHARES & Diversified & Local Inf. & 0.382 & 1.200 & $-3.087 * * *$ & 0.159 & 0.504 & $-2.887 * * *$ \\
\hline COMM & Advertiser & Diversified & 0.149 & 0.098 & 1.207 & 0.067 & 0.062 & -0.282 \\
\hline COMM & Advertiser & Local Inf. & 0.149 & 0.691 & $-1.950 *$ & 0.067 & 0.263 & $-3.682 * * *$ \\
\hline COMM & Diversified & Local Inf. & 0.098 & 0.691 & $-2.094 * *$ & 0.062 & 0.263 & $-4.071 * * *$ \\
\hline
\end{tabular}

Table 5 shows the results of our multivariate analysis. In order to identify the impact for each Facebook activity model in relation to the remaining two ones, we consider sets of three specifications and regress each response variable (i.e., LIKES, SHARES, or COMM) against the same set of control variables and three different pairs of dummy variables reflecting Facebook activity models: Advertiser and Local Informant in specifications (1), (4), and (7); Advertiser and Diversified in specifications (2), (5), and (8); and Local Informant and Diversified in specifications (3), (6), and (9). A few estimated coefficients for the control variables are statistically significant at levels between $5 \%$ and $10 \%$. Firstly, we observe that larger banks (LN.A) are more likely to get more share button clicks, possibly due to their wider customer reach. Secondly, SLBs with lower interest margin (i.e., NIM) are more effective in collecting shares. Thirdly, less profitable SLBs $(R O A)$ surprisingly get more share button clicks. We presume that this could be related to a situation in which increased expenditures on social media presence and communication with customers reduce the profitability in the short term, but simultaneously increase a bank's recognition. Finally, we observe that SLBs receive more likes in less urbanized areas (URBANIZ), where they are more likely to build stronger ties with local community members. The estimation results for our Facebook activity models confirm the outcomes of our univariate analysis. The Local Informant gets more likes and share button clicks than the Advertiser (4.5 likes and 0.6 shares per post more) and the Diversified models (3.2 likes and 0.6 shares per post more). As for the impact on comments, the Local Informant outperforms both remaining models, but the difference is statistically significant only in relation to the Diversified model. Finally, it is worth emphasizing that, similarly to the univariate analysis, there are no statistically significant differences in the impact exerted on Facebook users by SLBs conforming with the Advertiser or Diversified models. 
Table 5. Regression models. Response to SLBs' Facebook activity models (source: author's own calculations)

\begin{tabular}{|c|c|c|c|c|c|c|c|c|c|}
\hline & (1) & (2) & (3) & (4) & (5) & (6) & (7) & (8) & (9) \\
\hline Variables & LIKES & LIKES & LIKES & SHARES & SHARES & SHARES & COMM & COMM & COMM \\
\hline \multirow[t]{2}{*}{$L N . A$} & 0.647 & 0.647 & 0.647 & $0.434 * *$ & $0.434 * *$ & $0.434 * *$ & 0.0697 & 0.0697 & 0.0697 \\
\hline & $(0.733)$ & $(0.733)$ & $(0.733)$ & $(0.184)$ & $(0.184)$ & $(0.184)$ & $(0.0800)$ & $(0.0800)$ & $(0.0800)$ \\
\hline \multirow[t]{2}{*}{ NIM } & -88.91 & -88.91 & -88.91 & $30.08^{*}$ & $30.08^{*}$ & $30.08 *$ & -10.87 & -10.87 & -10.87 \\
\hline & $(54.60)$ & $(54.60)$ & (54.60) & $(17.82)$ & (17.82) & $(17.82)$ & (17.89) & (17.89) & $(17.89)$ \\
\hline \multirow[t]{2}{*}{ LOANS } & 3.240 & 3.240 & 3.240 & -0.0756 & -0.0756 & -0.0756 & -0.276 & -0.276 & -0.276 \\
\hline & $(2.230)$ & $(2.230)$ & $(2.230)$ & $(0.648)$ & $(0.648)$ & $(0.648)$ & $(0.350)$ & $(0.350)$ & $(0.350)$ \\
\hline \multirow[t]{2}{*}{ EQUITY } & 5.779 & 5.779 & 5.779 & 1.509 & 1.509 & 1.509 & -1.288 & -1.288 & -1.288 \\
\hline & $(19.62)$ & (19.62) & (19.62) & $(4.580)$ & $(4.580)$ & $(4.580)$ & (1.564) & (1.564) & (1.564) \\
\hline \multirow[t]{2}{*}{$R O A$} & 43.85 & 43.85 & 43.85 & $-63.74 * *$ & $-63.74 * *$ & $-63.74 * *$ & 27.15 & 27.15 & 27.15 \\
\hline & $(122.2)$ & $(122.2)$ & $(122.2)$ & $(30.43)$ & (30.43) & $(30.43)$ & (30.94) & (30.94) & (30.94) \\
\hline \multirow[t]{2}{*}{ UNEMPL } & 1.164 & 1.164 & 1.164 & -0.782 & -0.782 & -0.782 & 0.712 & 0.712 & 0.712 \\
\hline & $(7.232)$ & $(7.232)$ & $(7.232)$ & $(1.672)$ & $(1.672)$ & $(1.672)$ & $(1.111)$ & $(1.111)$ & $(1.111)$ \\
\hline \multirow[t]{2}{*}{ POPUL } & 1.957 & 1.957 & 1.957 & $-0.720^{*}$ & $-0.720 *$ & $-0.720 *$ & -0.189 & -0.189 & -0.189 \\
\hline & (1.966) & $(1.966)$ & $(1.966)$ & $(0.367)$ & $(0.367)$ & $(0.367)$ & $(0.376)$ & $(0.376)$ & $(0.376)$ \\
\hline \multirow[t]{2}{*}{ URBANIZ } & $-7.099 *$ & $-7.099 *$ & $-7.099 *$ & 0.0325 & 0.0325 & 0.0325 & 0.147 & 0.147 & 0.147 \\
\hline & (3.594) & (3.594) & (3.594) & $(0.523)$ & $(0.523)$ & $(0.523)$ & $(0.353)$ & $(0.353)$ & $(0.353)$ \\
\hline \multirow[t]{2}{*}{ Advertiser } & -1.203 & $-4.449 * * *$ & & 0.0587 & $-0.555^{*}$ & & 0.0321 & -0.492 & \\
\hline & (1.153) & (1.085) & & $(0.170)$ & $(0.294)$ & & $(0.0688)$ & $(0.313)$ & \\
\hline \multirow[t]{2}{*}{ Local Inf. } & $3.245 * *$ & & $4.449 * * *$ & $0.613 * *$ & & $0.555^{*}$ & $0.524 *$ & & 0.492 \\
\hline & $(1.296)$ & & $(1.085)$ & $(0.276)$ & & $(0.294)$ & $(0.276)$ & & $(0.313)$ \\
\hline \multirow[t]{2}{*}{ Diversified } & & $-3.245^{* *}$ & 1.203 & & $-0.613^{* *}$ & -0.0587 & & $-0.524 *$ & -0.0321 \\
\hline & & $(1.296)$ & $(1.153)$ & & $(0.276)$ & $(0.170)$ & & $(0.276)$ & $(0.0688)$ \\
\hline \multirow[t]{2}{*}{ Constant } & -5.741 & -2.496 & -6.945 & $-7.903^{* *}$ & $-7.290^{*}$ & $-7.844 * *$ & -0.815 & -0.291 & -0.782 \\
\hline & (17.09) & (16.78) & (16.38) & (3.956) & (3.942) & (3.915) & (1.653) & $(1.729)$ & $(1.650)$ \\
\hline Banks & 111 & 111 & 111 & 111 & 111 & 111 & 111 & 111 & 111 \\
\hline R-squared & 0.195 & 0.195 & 0.195 & 0.211 & 0.211 & 0.211 & 0.090 & 0.090 & 0.090 \\
\hline
\end{tabular}

Robust standard errors are presented in parentheses; characters *, **, and *** refer to statistical significance at the $10 \%, 5 \%$, and $1 \%$ levels, respectively.

\section{Facebook activity models and their relationship with bank growth}

Although the results from Table 5 indicate that a suitably designed informational policy in social media can significantly impact customer attention, the economic consequences of such policy are still unknown. Thus, Table 6 shows estimation results for the multivariate analysis concerning the relationship between a type of Facebook activity and bank growth. In the same manner as in Table 4, in order to investigate differences between each two Facebook activity models, we consider sets of three specifications and regress each response variable (i.e., $D E P O \triangle, L O A N \Delta$, and $A S$ SETA) against the same set of control variables and three different pairs of dummy variables reflecting Facebook activity models, that is, Advertiser and Local Informant in specifications (1), (4), and (7); Advertiser and Diversified in specifications (2), (5), and (8); and Local Informant and Diversified in specifications (3), (6), and (9).

A few control variables appear statistically significant. First, we observe that larger SLBs report higher deposit growth rates. Second, in line with market discipline literature (e.g., Martinez Peria \& Schmukler, 2001; Murata \& Hori, 2006; Hori, Ito, \& Murata, 2009), more profitable banks attract more depositors, which finally allows them to increase lending and, as a result, total assets. Third, we do not observe a similar phenomenon for the total equity to assets ratio (i.e., the estimation outcomes provide evidence for a negative relationship between equity to assets ratio and deposit growth), but it can be related to relatively limited financial sophistication of SLBs' depositors and a reduced willingness of well-capitalized banks to struggle for deposit financing. Fourth, we observe that SLBs' generate higher deposit growth in less urbanized areas. This observation should not be surprising if we take into account that such areas are the usual SLBs' strongholds. 
With reference to our binary variables representing Facebook activity models, we do not find any conclusive evidence. First, although regressions from Table 5 consistently proved that Local Informants win the race for the attention of Facebook users, we cannot provide evidence that such attention gains lead to new deposits or an increase in the deposit volume of existing customers. In a similar manner, all the coefficients for our Facebook activity models in the asset growth (ASSET $\Delta$ ) regressions are statistically insignificant. If the attention gains from Facebook activity have repercussions for bank growth, it appears to partly relate to the loan volumes. Specifications (4)-(6) show that the Diversified model stays behind the remaining two specialized models of Facebook activity, that is, Advertiser and Local Informant. Nevertheless, we cannot observe any significant differences between the impact exerted by the second and the third one of the above-mentioned Facebook activity models. As the evidence for the loan growth (LOAN $\Delta$ ) is inconclusive and it is not reflected in the evidence for the asset or deposit growth (ASSET $\Delta$ and DEPO $\Delta$, respectively), we conclude that SLBs applying the Local Informant model of Facebook activity are not able to easily enjoy economic benefits from the increased attention of Facebook users. In other words, members of a local society seem to be lured to a Facebook profile of the SLB if the bank widely discusses local affairs, but such Facebook users do not finally become the bank's clients and they do not place more savings in this bank. Thus, the informational strategy that proved to be the most efficient one from a pure media perspective, fails to be successful in the economic dimensions. Nevertheless, it is worth stressing that, in the case of SLBs, economic growth cannot be also easily achieved through more aggressive and advertising-oriented social media presence.

Table 6. Regression models. Facebook activity models and bank growth (source: author's own calculations)

\begin{tabular}{|c|c|c|c|c|c|c|c|c|c|}
\hline & (1) & (2) & (3) & (4) & (5) & (6) & (7) & (8) & (9) \\
\hline Variables & DEPO $\triangle$ & DEPO $\Delta$ & DEPO $\triangle$ & LOAN $\Delta$ & LOAN $\Delta$ & LOAN $\Delta$ & ASSET $\Delta$ & ASSET $\Delta$ & ASSET $\Delta$ \\
\hline \multirow[t]{2}{*}{$L N . A$} & $-0.0167^{*}$ & $-0.0167^{*}$ & $-0.0167 *$ & -0.0166 & -0.0166 & -0.0166 & -0.0126 & -0.0126 & -0.0126 \\
\hline & $(0.00963)$ & $(0.00963)$ & $(0.00963)$ & $(0.0122)$ & $(0.0122)$ & $(0.0122)$ & $(0.00869)$ & $(0.00869)$ & $(0.00869)$ \\
\hline \multirow[t]{2}{*}{ NIM } & 0.790 & 0.790 & 0.790 & -0.931 & -0.931 & -0.931 & 0.555 & 0.555 & 0.555 \\
\hline & $(0.966)$ & $(0.966)$ & $(0.966)$ & (1.189) & (1.189) & (1.189) & $(0.869)$ & $(0.869)$ & $(0.869)$ \\
\hline \multirow[t]{2}{*}{ LOANS } & 0.000900 & 0.000900 & 0.000900 & -0.00106 & -0.00106 & -0.00106 & 0.00900 & 0.00900 & 0.00900 \\
\hline & $(0.0669)$ & $(0.0669)$ & $(0.0669)$ & $(0.0936)$ & $(0.0936)$ & $(0.0936)$ & $(0.0592)$ & $(0.0592)$ & $(0.0592)$ \\
\hline \multirow[t]{2}{*}{ EQUITY } & $-0.725^{* *}$ & $-0.725^{* *}$ & $-0.725^{* *}$ & $-1.144 * *$ & $-1.144 * *$ & $-1.144 * *$ & $-0.689 * *$ & $-0.689 * *$ & $-0.689 * *$ \\
\hline & $(0.309)$ & $(0.309)$ & $(0.309)$ & $(0.462)$ & $(0.462)$ & $(0.462)$ & $(0.272)$ & $(0.272)$ & $(0.272)$ \\
\hline \multirow[t]{2}{*}{$R O A$} & $4.044 *$ & $4.044 *$ & $4.044^{*}$ & $7.234 * * *$ & $7.234 * * *$ & $7.234 * * *$ & $4.245^{* *}$ & $4.245^{* *}$ & $4.245^{* *}$ \\
\hline & $(2.132)$ & $(2.132)$ & $(2.132)$ & $(2.392)$ & $(2.392)$ & $(2.392)$ & (1.918) & (1.918) & (1.918) \\
\hline \multirow[t]{2}{*}{ UNEMPL } & -0.0421 & -0.0421 & -0.0421 & 0.0513 & 0.0513 & 0.0513 & -0.0303 & -0.0303 & -0.0303 \\
\hline & $(0.136)$ & $(0.136)$ & $(0.136)$ & $(0.162)$ & $(0.162)$ & $(0.162)$ & $(0.125)$ & $(0.125)$ & $(0.125)$ \\
\hline \multirow[t]{2}{*}{ POPUL } & 0.00522 & 0.00522 & 0.00522 & -0.00593 & -0.00593 & -0.00593 & 0.00508 & 0.00508 & 0.00508 \\
\hline & $(0.0277)$ & $(0.0277)$ & $(0.0277)$ & $(0.0389)$ & $(0.0389)$ & $(0.0389)$ & $(0.0251)$ & $(0.0251)$ & $(0.0251)$ \\
\hline \multirow[t]{2}{*}{ URBANIZ } & $-0.0894 *$ & $-0.0894 *$ & $-0.0894 *$ & 0.00651 & 0.00651 & 0.00651 & $-0.0858^{*}$ & $-0.0858^{*}$ & $-0.0858^{*}$ \\
\hline & $(0.0494)$ & $(0.0494)$ & $(0.0494)$ & $(0.0751)$ & $(0.0751)$ & $(0.0751)$ & $(0.0438)$ & $(0.0438)$ & $(0.0438)$ \\
\hline \multirow[t]{2}{*}{ Advertiser } & 0.0206 & -0.00878 & & $0.0412 * *$ & -0.0136 & & 0.0170 & -0.00834 & \\
\hline & $(0.0150)$ & $(0.0210)$ & & $(0.0183)$ & $(0.0225)$ & & $(0.0132)$ & $(0.0190)$ & \\
\hline \multirow[t]{2}{*}{ Local Inf. } & 0.0294 & & 0.00878 & $0.0549 * * *$ & & 0.0136 & 0.0253 & & 0.00834 \\
\hline & $(0.0207)$ & & $(0.0210)$ & $(0.0199)$ & & $(0.0225)$ & $(0.0188)$ & & $(0.0190)$ \\
\hline \multirow[t]{2}{*}{ Diversified } & & -0.0294 & -0.0206 & & $-0.0549 * * *$ & $-0.0412 * *$ & & -0.0253 & -0.0170 \\
\hline & & $(0.0207)$ & $(0.0150)$ & & $(0.0199)$ & $(0.0183)$ & & $(0.0188)$ & $(0.0132)$ \\
\hline \multirow[t]{2}{*}{ Constant } & $0.466^{* *}$ & $0.496 * *$ & $0.487 * *$ & $0.453^{*}$ & $0.508^{*}$ & $0.494 *$ & $0.378^{* *}$ & $0.403 * *$ & $0.395^{* *}$ \\
\hline & $(0.203)$ & $(0.210)$ & $(0.206)$ & $(0.253)$ & $(0.256)$ & $(0.255)$ & $(0.184)$ & $(0.189)$ & $(0.185)$ \\
\hline Banks & 111 & 111 & 111 & 111 & 111 & 111 & 111 & 111 & 111 \\
\hline R-squared & 0.156 & 0.156 & 0.156 & 0.201 & 0.201 & 0.201 & 0.171 & 0.171 & 0.171 \\
\hline
\end{tabular}

Robust standard errors are presented in parentheses; characters $* * *$, and $* * *$ refer to statistical significance at the $10 \%, 5 \%$, and $1 \%$ levels, respectively. 


\section{Conclusions}

Our study on the Facebook activity of Polish SLBs allowed us to identify three models of Facebook informational policy. The first model, the Advertiser, is concentrated on advertising a bank's products. The second one, the Local Informant, assumes high coverage of local events, comments on charitable undertakings, as well as thanks, wishes, and congratulations to local community members. The third one, the Diversified, is a combination of the other two models. The results from both univariate and multivariate analyses lead us to conclude that, in order to reach the highest recognition among Facebook users, a bank could consider an informational policy on Facebook in line with the Local Informant model. Indeed, the model brings the highest number of likes, share button clicks, and comments per each published post on a bank's Facebook page. Potentially, this result could be driven by the specificity of SLBs: as they are cooperatives, members of a local community usually expect them to be something more than a purely market- and profit-oriented company. Nevertheless, our findings suggest that drawing the attention of Facebook users is a different task than the conversion of such attention into bank growth. Regardless employed social media activity model, the analyzed SLBs grow in a similar manner, and the estimation results do not reveal consistent differences between deposit, loan or asset dynamics. Thus, we conjecture that SLBs' managers should very carefully enter the social media world.

Our study has one main limitation which is determined by the scope of Facebook activity of SLBs, and thus by the scope of data that can be employed in the research. Is should be noted that social media is still a new and innovative communication channel for small cooperatives. The median value of post per bank between 2010 and 2016 equals 111, but there are still some entities with only a minor Facebook presence, as the quarter of banks published less than 27 posts in the analyzed period. The limited number of banks applying active social media policy, poses a challenge from an econometric point of view, as it forces the researcher to thoroughly rethink the definition of variables and reasonably handle the number of explanatory variables in regression models. Additionally, it reduces possibilities of preparing an in-depth analysis which could investigate the impact of different Facebook activity models conditionally on other factors related to a bank's specificity or the competition it faces in its local market. Nevertheless, the developing nature of small local banks' social media activity should eliminate, or at least reduce, this limitation in the nearest future. This process is expected to open future research possibilities, related to the impact of distinct Facebook activity models on small local banks' performance, as well as to the banks' activity in the remaining, currently unutilized, social media.

\section{Funding}

This work was supported by the Polish National Science Center (Narodowe Centrum Nauki), under Grant 2017/25/B/HS4/00887 titled "Relacja przedsiębiorstwa z bankiem i jej ekonomiczne konsekwencje" ("Company and its bank - the relationship and its economic consequences").

\section{Disclosure statement}

The authors do not have any competing financial, professional, or personal interests from other parties.

\section{References}

Bolton, R. N. (2011). Customer engagement: opportunities and challenges for organizations. Journal of Service Research, 14(3), 272-274. https://doi.org/10.1177/1094670511414582

Cawsey, T., \& Rowley, J. (2016). Social media brand building strategies in B2B companies. Marketing Intelligence \& Planning, 34(6), 754-776. https://doi.org/10.1108/MIP-04-2015-0079

Ciciretti, R., Hasan, I., \& Zazzara, C. (2009). Do internet activities Add value? Evidence from the traditional banks. Journal of Financial Services Research, 35(1), 81-98. https://doi.org/10.1007/s10693-008-0039-2

Cvijikj, I. P., \& Michahelles, F. (2011, October). A case study of the effects of moderator posts within a Facebook brand page. In Social Informatics. Third International Conference, SocInfo 2011 Singapore. Proceedings (pp. 161-170).

Delgado, J., Hernando, I., \& Nieto, M. J. (2007). Do European primarily internet banks show scale and experience efficiencies? European Financial Management, 13(4), 643-671. https://doi.org/10.1111/j.1468-036X.2007.00377.x

DeYoung, R., Lang, W. W., \& Nolle, D. L. (2007). How the Internet affects output and performance at community banks. Journal of Banking and Finance, 31(4), 1033-1060. https://doi.org/10.1016/j.jbankfin.2006.10.003

Durkin, M., McGowan, P., \& Murray L. (2014). Perspectives on the potential for social media to improve communication in small business-bank relationships. Entrepreneurship and Innovation, 15(4), 251-264. https://doi.org/10.5367/ijei.2014.0163

Edelman, D. (2010). Branding in the digital age: you're spending your money in all the wrong places. Harvard Business Review, $88,62-69$.

eMarketer, Worldwide Social Network Users: eMarketer's Estimates and Forecast for 2016-2021. (2017, June). Retrieved from https://www.emarketer.com/Article/eMarketer-Updates-Worldwide-Social-Network-User-Figures/1016178

Farshid, M., Plangger, K., \& Nel, D. (2011). The social media faces of major global financial service brands. Journal of Financial Services Marketing, 16(3-4), 220-229. https://doi.org/10.1057/fsm.2011.19

Filip, D., Jackowicz, K., \& Kozłowski, Ł. (2017). Influence of internet and social media presence on small, local bank's market power. Baltic Journal of Economics, 17(2), 190-214. https://doi.org/10.1080/1406099X.2017.1376856 
Gallaugher, J., \& Ransbotham, S. (2010). Social media and customer dialog management at starbucks. MIS Quarterly Executive, 9 , 197-212.

Hansson, L., Wrangmo, A., \& Søilen, K. S. (2013). Optimal ways for companies to use Facebook as a marketing channel. Journal of Information, Communication and Ethics in Society, 11(2), 112-126. https://doi.org/10.1108/JCES-12-2012-0024

Hernando, I., \& Nieto, M. J. (2007). Is the Internet delivery channel changing banks' performance? The case of Spanish banks. Journal of Banking and Finance, 31(4), 1083-1099. https://doi.org/10.1016/j.jbankfin.2006.10.011

Hitt, L. M., \& Frei, F. X. (2002). Do better customers utilize electronic distribution channels? The case of PC banking. Management Science, 48(6), 732-748. https://doi.org/10.1287/mnsc.48.6.732.188

Hori, M., Ito, Y., \& Murata, K. (2009). Do depositors respond rationally to bank risks? Evidence from Japanese banks during crises. Pacific Economic Review, 14(5), 581-592. https://doi.org/10.1111/j.1468-0106.2009.00470.x

Hsu, L., \& Lawrence, B. (2016). The role of social media and brand equity during a product recall crisis: A shareholder value perspective. International Journal of Research in Marketing, 33(1), 59-77. https://doi.org/10.1016/j.ijresmar.2015.04.004

Kaplan, A. M., \& Haenlein, M. (2010). Users of the world unite! The challenges and opportunities of social media. Business Horizons, 53(1), 59-68. https://doi.org/10.1016/j.bushor.2009.09.003

Kaufman, L., \& Rousseeuw, P. (1990). Finding groups in data: An introduction to cluster analysis. John Wiley and Sons, New York. https://doi.org/10.1002/9780470316801

Kim, G., Lim, H., \& Brymer, R. A. (2015b). The effectiveness of managing social media on hotel performance. International Journal of Hospitality Management, 44, 165-171. https://doi.org/10.1016/j.ijhm.2014.10.014

Kim, S., Koh, Y., Cha, J., \& Lee, S. (2015a). Effects of social media on firm value for U.S. restaurant companies. International Journal of Hospitality Management, 49, 40-46. https://doi.org/10.1016/j.ijhm.2015.05.006

Laroche, M., Habibi, M. R., \& Richard, M. O. (2013). To be or not to be in social media: how brand loyalty is affected by social media? International Journal of Information Management, 33(1), 76-82. https://doi.org/10.1016/j.ijinfomgt.2012.07.003

Laroche, M., Habibi, M. R., Richard, M. O., \& Sankaranarayanan, R. (2012). The effects of social media based brand communities on brand community markers, value creation practices, brand trust and brand loyalty. Computers in Human Behavior, 28(5), 1755-1767. https://doi.org/10.1016/j.chb.2012.04.016

Larsson, A., \& Viitaoja, Y. (2017). Building customer loyalty in digital banking: A study of bank staff's perspectives on the challenges of digital CRM and loyalty. International Journal of Bank Marketing, 35(6), 858-877. https://doi.org/10.1108/IJBM-08-2016-0112

Lipsman, A., Mudd, G., Rich, M., \& Bruich, S. (2012). The power of 'like': how brands reach (and influence) fans through socialmedia marketing. Journal of Advertising Research, 52, 40-52. https://doi.org/10.2501/JAR-52-1-040-052

Mangold, W. G., \& Faulds, D. J. (2009). Social media: the new hybrid element of the promotion mix. Business Horizons, 52(4), 357-365. https://doi.org/10.1016/j.bushor.2009.03.002

Martinez Peria, M. S., \& Schmukler, S. L. (2001). Do depositors punish banks for bad behavior? Market discipline, deposit insurance, and banking crises. Journal of Finance, 56(3), 1029-1051. https://doi.org/10.1111/0022-1082.00354

Murata, K., \& Hori, M. (2006). Do small depositors exit from bad banks? Evidence from small financial institutions in Japan. Japanese Economic Review, 57(2), 260-278. https://doi.org/10.1111/j.1468-5876.2006.00363.x

Onay, C., \& Ozsoz, E. (2013). The impact of internet-banking on brick and mortar branches: The case of Turkey. Journal of Financial Services Research, 44(2), 187-204. https://doi.org/10.1007/s10693-011-0124-9

Ozdora-Aksaka, E., \& Atakan-Duman, S. (2015). The online presence of Turkish banks: Communicating the softer side of corporate identity. Public Relations Review, 41(1), 119-128. https://doi.org/10.1016/j.pubrev.2014.10.004

Paniagua, J., \& Sapena, J. (2014). Business performance and social media: Love or hate? Business Horizons, 57(6), 719-728. https://doi.org/10.1016/j.bushor.2014.07.005

Plangger, K. (2012). The power of popularity: how the size of a virtual community adds to firm value. Journal of Public Affairs, 12(2), 145-153. https://doi.org/10.1002/pa.1416

Polish Financial Supervision Authority [PFSA]. (2017). Informacja o sytuacji banków spółdzielczych i zrzeszających w I kwartale 2017 roku [Information about the situation of cooperative banks and their affiliating entities in 1Q 2017]. Retrieved from http://www.knf.gov.pl

Pozza, I. D. (2014). Multichannel management gets "social”. European Journal of Marketing, 48(7/8), $1274-1295$. https://doi.org/10.1108/EJM-10-2012-0598

Silver, L., \& Vegholm, F. (2009). The dyadic bank-SME relationship. Journal of Small Business and Enterprise Development, 16(4), 615-627. https://doi.org/10.1108/14626000911000956

Swani, K., \& Milne, G. R. (2017). Evaluating Facebook brand content popularity for service versus goods offerings. Journal of Business Research, 79, 123-133. https://doi.org/10.1016/j.jbusres.2017.06.003

Swani, K., Milne, G., \& Brown, B. P. (2013). Spreading the word through likes on Facebook: Evaluating the message strategy effectiveness of Fortune 500 companies. Journal of Research in Interactive Marketing, 7(4), $269-294$. https://doi.org/10.1108/JRIM-05-2013-0026

Tang, C., Mehl, M. R., Eastlick, M. A., He, W., \& Card, N. A. (2016). A longitudinal exploration of the relations between electronic word-of-mouth indicators and firms' profitability: Findings from the banking industry. International Journal of Information Management, 36(6, part A), 1124-1132. https://doi.org/10.1016/j.ijinfomgt.2016.03.015

Tsimonis, G., \& Dimitriadis, S. (2014). Brand strategies in social media. Marketing Intelligence \& Planning, 32(3), 328-344. https://doi.org/10.1108/MIP-04-2013-0056

van Doorn, J., Onrust, M., Verhoef, P. C., \& Bügel, M. (2017). The impact of corporate social responsibility on customer attitudes and retention - the moderating role of brand success indicators. Marketing Letters, 28(4), 607-619. https://doi.org/10.1007/s11002-017-9433-6 